\title{
ANALISIS PERBANDINGAN RASIO PROFITABILITAS PADA PT. MANDOM INDONESIA TBK DENGAN PT. MARTINA BERTO TBK
}

\author{
Rizki Ahdiaryani \\ Prodi Manajemen Sekolah Tinggi Ilmu Ekonomi (STIE) Bima \\ Email: rizkiahdiaryanii16stiebima@gmail.com \\ Alwi \\ Prodi Manajemen Sekolah Tinggi Ilmu Ekonomi (STIE) Bima \\ Email: Alwi_muhammad1317@yahoo.co.id
}

\begin{abstract}
This study aims to determine and analyze the ratio of profitability ratios using the ROE ratio at PT. Mandom Indonesia Tbk with PT. Martina Berto Tbk. This type of research is a comparative study, with the research sample is the annual financial statements for the last 9 years from 2010 to 2018. The sampling technique used was purposive sampling. Data collection uses observation, documentation and heritage studies. The data analysis method used is the t-test separated variant test and also using the SPSS program. From the results of the t-test separated variant test with the help of the SPSS program, the calculated $t$ value of 1.971 was obtained. If compared between the value of tcount with ttable, then tcount is smaller than ttable $(1,971<2,120)$. The results of this study concluded that there were differences in profitability ratios between PT. Mandom Indonesia Tbk with PT. Martina Berto Tbk.
\end{abstract}

Keywords: Profitability Ratio, ROE

\begin{abstract}
Abstrak
Penelitian ini bertujuan untuk mengetahui dan menganalisis perbandingan rasio profitabilitas dengan menggunakan rasio ROE pada PT. Mandom Indonesia Tbk dengan PT. Martina Berto Tbk. Jenis penelitian yang digunakan adalah penelitian komparatif, dengan sampel penelitian adalah laporan keuangan tahunan selama 9 tahun terakhir dari tahun 2010 sampai tahun 2018. Teknik sampling yang digunakan adalah purposive sampling. Pengumpulan data menggunakan observasi, dokumentasi dan studi pusaka. Metode analisis data yang digunakan adalah uji t-test separated varian dan juga dengan menggunakan program SPSS. Dari hasil uji t-test separated varian dengan bantuan program SPSS maka diperoleh nilai t hitung sebesar 1,971. Jika di bandingkan antara nilai $t_{\text {hitung dengan }} t_{\text {tabel, }}$ maka thitung lebih kecil dari $t_{\text {tabel }}(1,971<2,120)$. Hasil dari penelitian ini menyimpulkan bahwa ada perbedaan rasio profitabilitas antara PT. Mandom Indonesia Tbk dengan PT. Martina Berto Tbk.
\end{abstract}

Kata Kunci : Rasio Profitabilitas, ROE 


\section{PENDAhUluaN}

Perkembangan teknologi yang semakin canggih membuat perusahaan harus mampu menciptakan nilai bagi perusahaan. Persaingan bisnis di berbagai sektor akan membuat manejemen perusahaan harus mengatur strategistrategi yang baru agar perusahaan dapat bertahan menjalankan bisnisnya. Perusahaan yang mampu terus bertahan dapat dilihat dari kinerja keuangan yang baik dan terkontrol. Kinerja keuangan suatu perusahaan merupakan gambaran kegiatan yang dilakukan untuk mencapai tujuan bisnis pada suatu periode tertentu. Kinerja perusahaan dapat diukur dengan menganalisa dan mengevaluasi laporan keuangan dimasa lalu dan digunakan untuk memprediksi posisi keuangan dan kinerja dimasa depan.

Pada umumnya Kinerja kuangan dapat diukur dengan menggunakan Rasio Profitabilitas. Rasio Profitabilitas perusahaan dapat mengukur kinerja keuangan dengan baik, dan mengukur kemampuan perusahaan untuk memperoleh laba, sehingga perusahaan dapat mengetahui laba bersih dan laba kotor yang diperoleh perusahaan dalam suatu periode tertentu. Adanya metode ini akan menunjukan kemampuan perusahaan dalam mendapatkan keuntungan selama periode tertentu dan apakah prusahaan akan menciptakan nilai atau tidak.

Dalam penelitian ini, peneliti mencoba membandingkan kinerja keuangan yang diukur dengan menggunakan rasio profitabilitas pada dua perusahaan besar yang ada di Indonesia yaitu PT. Mandom Indonesia Tbk dan PT. Martina Berto Tbk. Dalam pengukuran rasio profitabilitas itu sendiri digunakan rasio Return On Equity (ROE). Pemilihan ROE sebagai alat ukur didasari pada keinginan peneliti untuk mengukur dan membandingkan kemampuan kedua perusahaan tersebut dalam menghasilkan laba dengan aktiva yang digunakan. Rasio ini menunjukkan pula tingkat efesiensi investasi yang nampak pada tingkat perputaran aktiva.

PT Mandom Indonesia Tbk merupakan perusahaan yang berbasis di Indonesia yang bergerak dalam pembuatan produk kosmetik. Kegiatan bisnis utamanya bergerak dalam pembuatan dan perdagangan produk perawatan kulit dan rias wajah, produk perawatan rambut, parfum, bahan pembersih dan produk perawatan pribadi lainnya. Merek-merek utama Perusahaan adalah Gatsby, Pixy, dan Pucelle. Selain itu, Perusahaan memproduksi beberapa produk dengan merek Tancho, Mandom, Spalding, Lovillea, Miratone. Perusahaan memasarkan produknya sebagian besar di Indonesia, namun, juga mengekspor produknya ke pasar luar negeri, seperti Uni Emirat Arab (UEA), Jepang, India, Malaysia, Thailand, dan lain-lain (www.mandom.co.id/en/annual-report)

Sedangkan PT. Martina Berto Tbk merupakan perusahaan yang

memproduksi kosmetik dan jamu yang bermarkas di Jakarta, Indonesia. Pada tahun 2012, Perusahaan memiliki pangsa pasar sebesar 2,8\% pada kecantikan \& produk perawatan pribadi, $12,7 \%$ pada kosmetik warna dan $2,16 \%$ pada produk perawatan kulit di Indonesia. Berdasarkan Anggaran Dasar Perusahaan, ruang lingkup kegiatan Perusahaan terutama meliputi bidang manufaktur dan perdagangan jamu tradisional dan barang-barang kosmetika, serta perawatan kecantikan. Produkproduk Martina Bento menggunakan merek-merek, berikut ini: Sariayu, PAC, Biokos, Caring Colours, Cempaka, Dewi Sri SPA, Belia, Mirabella, Rudy Hadisuwarno, Solusi dan Jamu Garden. Saat ini, Martina 
Berto juga memiliki 24 gerai Martha Tilaar Shop (dulu bernama Puri Ayu). (www.manrtina berto.co.id/investor.php).

Pada PT. Mandom Indonesia Tbk ditemukan bahwa perusahaan sedang mengalami masalah keuangan terutama modal yang diinvestasikan cenderung lebih besar dibandingkan laba bersih yang diterima. Artinya kondisi keuangan perusahaan harus segera diatasi agar tidak berdampak pada kebangkrutan perusahaan. Begitu pula halnya yang dialami oleh PT. Martina Berto Tbk, perusahaan ini mengalami masalah pada kondisi keuangan perusahaan. Namun gambaran permasalahan tersebut perlu dilakukan penelitian lanjutan untuk menganalisa dengan data-data empiris yang ada dari perusahaan yaitu laporan keuangan tahunan sebagai pembuktian bahwa perusahaan apakah sedang mengalami masalah keuangan atau tidak

Berdasarkan uraian tersebut diatas, maka peneliti tertarik untuk mengangkatnya menjadi sebuah penelitian dengan judul "ANALISIS PERBANDINGAN RASIO PROFITABILITAS PADA PT.MANDOM INDONESIA TBK DENGAN PT. MARTINA BERTO TBK"

\section{TINJAUAN PUSTAKA Rasio Keuangan}

Rasio keuangan merupakan alat analisis untuk menjelaskan hubungan tertentu antara elemen yang satu dengan elemen yang lainnya dalam suatu laporan keuangan (financial statement). Analisis rasio keuangan merupakan salah satu teknik dalam menganalisis laporan keuangan untuk menilai kinerja keuangan suatu perusahaan dengan menghubungkan berbagai perkiraan yang terdapat pada laporan keuangan dalambentuk rasio keuangan yang menjelaskan kepada penganalisis mengenai keadaan atau posisi keuangan suatu perusahaan.

Menurut Munawir (2010:64) rasio keuangan adalah rasio yang menggambarkan suatu hubungan atau pertimbangan (mathematical relationship) antara suatu jumlah tertentu dengan jumlah yang lain, denganmenggunakan alat analisa berupa rasio yang menjelaskan gambaran kepada penganalisa tentang baik atau buruk keadaan keuangan perusahaan terutama apabila angka rasio tersebut dibandingkan dengan angka rasio pembanding yang digunakan sebagai standar.

\section{Return On Equity (ROE)}

Return on Equity merupakan perbandingan antara laba bersih sesudah pajak dengan total ekuitas. Return on equity merupakan suatu pengukuran dari penghasilan yang tersedia bagi para pemilik perusahaan (baik pemegang saham biasa maupun pemegang saham preferen) atas modal yang mereka investasikan didalam perusahaan (Harahap, 2015:305).

Return on Equity adalah rasio yang memperlihatkan sejauh manakah perusahaan mengelola modal sendiri secara efektif, mengukur tingkat keuntungan dari investasi yang dilakukan pemilik modal sendiri atau pemegang saham perusahaan (Sawir, 2015:81).

Semakin tinggi ROE maka akan semakin baik bagi para pemegang saham atas dana yang telah investasikan. Standar Rasio untuk Return On Equity adalah 40\% (Kasmir, 2014:201).

Adapun ROE dapat dihitung dengan rumus :

$$
\begin{aligned}
& \text { ROE }=\frac{\text { Laba Bersih }}{\text { Ekuitas }} \times 100 \% \\
& \text { Berikut } \begin{array}{c}
\text { tabel standar rasio } \\
\text { profitabilitas menurut Kasmir } \\
(2014: 208):
\end{array}
\end{aligned}
$$

Tabel 1. Standar Rasio Profitabilitas

\begin{tabular}{|c|c|c|c|}
\hline No & Rasio & Standar & Kategori \\
\hline 1 & Gross Profit & $24,90 \%$ & Baik \\
\hline
\end{tabular}




\begin{tabular}{|c|l|c|c|}
\hline \hline & Margin (GPM) & & \\
\hline 2 & $\begin{array}{l}\text { Operating } \\
\text { Profot Margin } \\
(\text { OPM) }\end{array}$ & $10,80 \%$ & Baik \\
\hline 3 & $\begin{array}{l}\text { Net Profit } \\
\text { Margin (NPM) }\end{array}$ & $20 \%$ & Baik \\
\hline 4 & $\begin{array}{l}\text { Return On } \\
\text { Assets (ROA) }\end{array}$ & $30 \%$ & Baik \\
\hline 5 & $\begin{array}{l}\text { Return On } \\
\text { Equity (ROE) }\end{array}$ & $40 \%$ & Baik \\
\hline
\end{tabular}

Sumber : Kasmir 2014

\section{Kerangka Pikir}

Untuk memberikan gambaran tentang penelitian ini maka penulis menyajikan dalam bentuk kerangka pikir, yaitu sebuah bagan yang berisi tentang arah hubungan antara variabel penelitian seperti berikut ini :

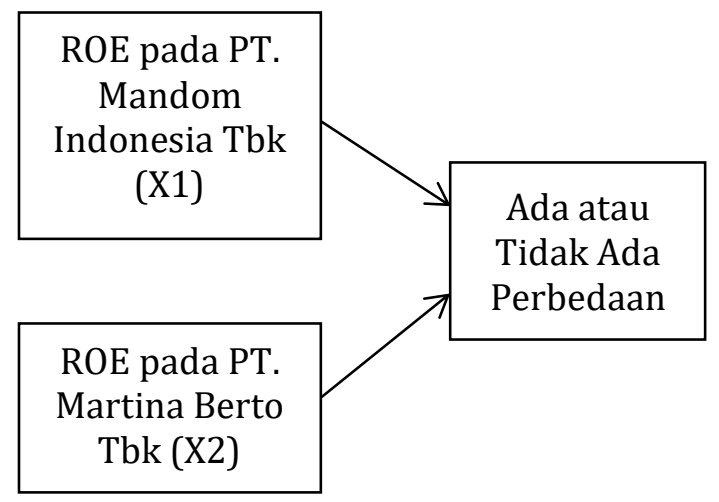

\section{Hipotesis}

Hipotesis merupakan jawaban sementara terhadap rumusan masalah penelitian, dimana rumusan masalah penelitian telah dinyatakan dalam bentuk kalimat pernyataan. Dikatakan sementara karena jawaban yang diberikan baru berdasarkan pada teori yang relevan, belum didasarkan pada fakta-fakta empiris yang diperoleh melalui pengumpulan data, (Sugiyono, 2013)

Adapun hipotesis yang diajukan dalam penelitian ini adalah :

$\mathrm{H}_{0} ; \mu_{1} \neq \mu_{2}$, ada perbedaan rasio profitabilitas antara PT. Mandom Indonesia Tbk dengan PT. Martina Berto Tbk.
$\mathrm{H}_{\mathrm{a}} ; \mu_{1}=\mu_{2}$, tidak ada perbedaan rasio profitabilitas antara PT. Mandom Indonesia Tbk dengan PT. Martina Berto Tbk.

\section{METODE PENELITIAN}

\section{Jenis Penelitian}

Jenis penelitian ini adalah Komparatif. Penelitian komparatif adalah penelitian yang bersifat membandingkan antara variabel yang satu dengan yang lain. Dalam hal ini membandingkan antara ROE pada PT. Mandom Indonesia Tbk (variabel X1) dengan ROE pada PT. Martina Berto Tbk (variabel X2).

\section{Instrumen Penelitian}

Instrumen penelitian yang digunakan yaitu daftar tabel berisi laba bersih dan ekuitas yang diperoleh dari data laporan keuangan tahunan PT. Mandom Indonesia Tbk dengan PT. Martina Berto Tbk yang dapat diakses di laman website Bursa efek Indonesia (BEI) yaitu www.idx.co.id karena kedua perusahaan tersebut sudah go public.

\section{Populasi Dan Sampel Penelitian}

Populasi dalam penelitian ini adalah Laporan Keuangan Berupa Laporan Neraca dan Laba rugi pada PT. Mandom Indonesia Tbk dan PT. Martina Indonesia Tbk. Dari mulai kedua perusahaan Listing Di BEI, PT. Mandom Indonesia Tbk yaitu dari tahun 1993 sampai 2018 dan PT. Martina Berto Tbk dari tahun 2011 sampai dengan 2018.

Sampel yang digunakan dalam penelitian ini adalah :

a. Laporan keuangan pada PT. Mandom Indonesia Tbk selama 9 tahun terakhir yaitu dari tahun 2010 sampai tahun 2018.

b. Laporan keuangan pada PT. Martina Berto Tbk selama 9 tahun terakhir yaitu dari tahun 2010 sampai tahun 2018.

Teknik sampling yang digunakan adalah sampling purposive, yaitu 
pengambilan sampel berdasarkan pertimbangan peneliti dimana sampel selama 9 tahun terakhir dianggap sudah mewakili keseluruhan data populasi yang ada dan sudah go public serta tercatat di Bursa efek Indonesia (BEI).

\section{Lokasi Dan Waktu Penelitian}

Penelitian ini dilakukan pada PT. Mandom Indonesia Tbk yang berlokasi di kawasan industri Cikarang Barat Bekasi. Kemudian PT. Martina Berto Tbk Yang berlokasi di kawasan industry Pulogadung - Jakarta

Waktu penelitian ini dilakukan selama dua bulan yaitu dari bulan januari 2020 sampai bulan februari 2020 .

\section{Teknik Pengumpulan Data}

Teknik pengumpulan data yang digunakan yaitu :

a. Observasi yaitu melakukan pengamatan dan pencatatan secara sistematik terhadap gejala yang tampak pada objek penelitian.

b. Dokumentasi adalah kumpulan dari dokumen-dokumen yang dapat memberikan keterangan atau bukti yang berkaitan dengan proses pengumpulan dan pengelolaan dokumen secara sistematis serta menyebar luaskan kepada pemakai informasi tersebut.

c. Studi pustaka merupakan tahap yang penting dalam kegiatan penelitian yang merupakan rangkaian proses pengayaan ilmu pengetahuan. Mengingat eratnya keterkaitan antara penelitian dengan pengetahuan yang sudah ada maka dalam melakukan kegiatan penelitian, seorang peneliti harus dekat dengan perpustakaan sebagai gudang ilmu pengetahuan.

\section{Jenis Dan Sumber Data}

Jenis Data yang digunakan dalam penelitian ini adalah data kuantitatif yaitu data yang dapat dihitung atau diukur dengan angka, dalam hal ini data berupa laporan keuangan tahunan pada PT. Mandom Indonesia Tbk dan PT. Martina Berto Tbk.

Sumber Data dalam penelitian ini adalah sekunder yaitu data yang diperoleh secara tidak langsung pada objek penelitian dengan mengakses website IDX atau website kedua perusahaan.

\section{Teknik Analisa Data}

Dalam penelitian ini teknik analisis data yang digunakan antara lain :

1. Analisis Rasio Keuangan

Analisa rasio keuangan untuk menghitung rasio profitabilitas pada PT. Mandom Indonesia Tbk dan PT. Martina Berto Tbk adalah dengan menggunakan Rasio Return On Equity.

Rumus :

a. $X_{1} R O E_{\text {Mandom }}=\frac{\text { Laba Bersih }}{\text { Ekuitas }} \times 100 \%$

b. $X_{2} R O E_{\text {Martina Berto }}=$ $\frac{\text { Laba Bersih }}{\text { Ekuitas }} \times 100 \%$

2. Analisis Statistik Teknik analisa data statistik yang digunakan untuk penelitian komparatif yaitu dengan menggunakan uji t-test separated varian.

Rumus t-test Separated Varian (Sugiyono, 2013):

$$
t=\frac{\bar{X}_{1}-\bar{X}_{2}}{\sqrt{\frac{s_{1}^{2}}{n_{1}}+\frac{s_{2}^{2}}{n_{2}}}}
$$




\section{HASIL DAN PEMBAHASAN Analisis Rasio Keuangan}

Untuk mengetahui perbandingan data rasio profitabilitas dengan menggunakan rasio ROE yang ada pada PT. Mandom Indonesia Tbkdan PT. Martina Berto Tbk selama 9 (sembilan) tahun terakhir maka dapat dilihat pada tabel berikut :

Tabel 2.

Perkembangan ROE pada PT. Mandom Indonesia Tbk dengan PT. Martina Berto Tbk dari tahun 2010 sampai tahun 2018

\begin{tabular}{|c|c|c|}
\hline Perusahaan & Tahun & ROE \\
\hline PT. Mandom & 2010 & $13,86 \%$ \\
\cline { 2 - 3 } Indonesia Tbk & 2011 & $13,72 \%$ \\
\cline { 2 - 3 } & 2012 & $13,71 \%$ \\
\cline { 2 - 3 } & 2013 & $13,54 \%$ \\
\cline { 2 - 3 } & 2014 & $14,0 \%$ \\
\cline { 2 - 3 } & 2015 & $31,8 \%$ \\
\cline { 2 - 3 } & 2016 & $9,1 \%$ \\
\cline { 2 - 3 } & 2017 & $9,6 \%$ \\
\cline { 2 - 3 } Berto Tbk & 2018 & $8,8 \%$ \\
\cline { 2 - 3 } & 2010 & $31,44 \%$ \\
\cline { 2 - 3 } & 2011 & $10,65 \%$ \\
\cline { 2 - 3 } & 2012 & $10,48 \%$ \\
\cline { 2 - 3 } & 2013 & $3,58 \%$ \\
\cline { 2 - 3 } & 2014 & $0,95 \%$ \\
\cline { 2 - 3 } & 2015 & $-3,24 \%$ \\
\cline { 2 - 3 } & 2016 & $2,00 \%$ \\
\cline { 2 - 3 } & 2017 & $-5,98 \%$ \\
\cline { 2 - 3 } & 2018 & $-37,98 \%$ \\
\hline
\end{tabular}

Sumber : Data Sekunder yang diolah 2020

Berdasarkan data yang ditunjukkan pada tabel diatas tentang perkembangan rasio profitabilitas yang diukur dengan nilai ROE pada PT. Mandom Indonesia Tbk terlihat bahwa selama 9 (sembilan) tahun terakhir yaitu dari tahun 2010 sampai tahun 2018. Persentase ini dari tahun ketahun mengalami penurunan dibawah standar yang telah ditetapkan yaitu $40 \%$. Ini berarti bahwa kinerja dari perusahaan masuk dalam kategori tidak baik/buruk. Perusahaan dianggap tidak mampu mendapatkan laba bersih secara maksimal sedangkan modal yang tersedia dan telah dikeluarkan terus meningkat dari tahun ke tahun.

Hal ini akan sangat mengganggu kinerja keuangan dan stabilitas keuangan perusahaan. Rendahnya nilai persentase ROE disebabkan karena laba bersih cenderung lebih kecil daripada modal yang dikeluarkan. Begitu pula halnya yang terjadi pada PT. Martina Berto Tbk, nilai ROE berada dibawah standar yang telah ditetapkan artinya perusahaan memiliki kinerja keuangan yang juga tidak baik/buruk dan beresiko mengalami kerugian bahkan kebangkrutan, hal ini dapat terlihat pada tahun 2015, 2017 dan 2018 perusahaan justru mengalami kerugian.

\section{Analisis Statistik \\ Uji t-test separated varian}

Untuk menghitung nilai ROE secara statistik maka dapat menggunakan rumus t-test separated varian dengan bantuan program SPSS. Penggunaan program SPSS bertujuan untuk memudahkan proses perhitungan t-test separated varian sehingga diperoleh hasil olah data sebagai berikut :

Group Statistics

\begin{tabular}{|rr|r|r|r|r|}
\hline PERUSAHAAN & N & Mean & $\begin{array}{c}\text { Std. } \\
\text { Deviatio } \\
\mathrm{n}\end{array}$ & $\begin{array}{c}\text { Std. Error } \\
\text { Mean }\end{array}$ \\
\hline \multirow{2}{*}{1,00} & 9 & 14,2367 & 6,95647 & 2,31882 \\
& 2,00 & 9 & 1,3222 & 18,3795 & 6,12650 \\
\hline
\end{tabular}

Terlebih dahulu dilakukan pengujian varian data homogen atau tidak yang bertujuan untuk penentuan nilai derajat kebebasan (dk) pada saat pengujian nilai $t_{\text {hitung. Untuk menguji varian datanya }}$ homogen atau tidak maka diuji dengan uji F. Nilai uji $F_{\text {hitung }}$ ini selanjutnya dibandingkan dengan nilai $\mathrm{F}_{\text {tabel }}$ dengan $\mathrm{dk}$ pembilang $\left(\mathrm{n}_{1}-1=9-1=8\right)$ dan $\mathrm{dk}$ 
penyebut $\left(\mathrm{n}_{2}-1=9-1=8\right)$ dan taraf kesalahan $5 \%$ maka diperoleh nilai $\mathrm{F}_{\text {tabel }}$ sebesar 3,44. Ketentuan uji F, Bila $F_{\text {hitung }}$ lebih kecil dari $\mathrm{F}_{\text {tabel }}(\mathrm{Fh}<\mathrm{Ft}$ ) maka variannya Homogen dan sebaliknya (Sugiyono, 2013). Ternyata $F_{\text {hitung }}<F_{\text {tabel }}$ $(2,316<3,44)$ maka dapat disimpulkan variannya homogen.

Jadi nilai $t_{\text {hitung }}$ adalah sebesar 1,971 kemudian nilai $t_{\text {hitung }}$ tersebut akan dibandingkan dengan $t_{\text {tabel, }}$ karena $n 1=n 2$ dan variannya homogen maka derajat kebebasan $(\mathrm{dk})=\mathrm{n}_{1}+\mathrm{n}_{2}-2=9+9-2=$ 16, uji dua pihak dan taraf kesalahan $5 \%$ $(0,05)$ di dapat nilai $t_{\text {tabel }}$ (pada lampiran tabel daftar distribusi $t$ ) adalah sebesar 2,120 .

\section{Ketentuan penerimaan dan penolakan hipotesis :}

Jika $t_{\text {hitung }}$ lebih kecil dari $t_{\text {tabel }}\left(t_{\text {hitung }}<\right.$ $\left.t_{\text {tabel }}\right)$ maka $\mathrm{H}_{0}$ diterima dan $\mathrm{H}_{\mathrm{a}}$ ditolak dan sebaliknya (Sugiyono, 2013).

Hipotesis teoritis yang diajukan adalah diduga ada perbedaan rasio profitabilitas antara PT. Mandom Indonesia Tbk dengan PT. Martina Berto Tbk.

\section{Hipotesis Statistik :}

$\mathrm{H}_{0} ; \mu_{1} \neq \mu_{2}$, ada perbedaan rasio profitabilitas antara PT. Mandom Indonesia Tbk dengan PT. Martina Berto Tbk.

$\mathrm{H}_{\mathrm{a}} ; \mu_{1}=\mu_{2}$, tidak ada perbedaan rasio profitabilitas antara PT. Mandom Indonesia Tbk dengan PT. Martina Berto Tbk.

Jika di bandingkan antara nilai $t_{\text {hitung }}$ dengan $t_{\text {tabel, }}$ maka $t_{\text {hitung }}$ lebih kecil dari $t_{\text {tabel }}(1,971<2,120)$, sesuai ketentuan maka jatuh pada daerah penerimaan $\mathrm{H}_{0}$ yang artinya $\mathrm{H}_{0}$ diterima dan Ha ditolak. Jadi hipotesis alternatif yang menyatakan bahwa ada perbedaan rasio profitabilitas antara PT. Mandom Indonesia Tbk dengan PT. Martina Berto Tbk yang diterima.

\section{PENUTUP \\ Simpulan}

1. Dari hasil uji t-test separated varian dengan bantuan program SPSS maka diperoleh nilai t hitung sebesar 1,971. Jika di bandingkan antara nilai thitung dengan $t_{\text {tabel}}$, maka $t_{\text {hitung }}$ lebih kecil dari $t_{\text {tabel }}(1,971<2,120)$, sehingga jatuh pada daerah penerimaan $\mathrm{H}_{0}$ yang artinya $\mathrm{H}_{0}$ diterima dan $\mathrm{H}_{\mathrm{a}}$ ditolak.

2. Hipotesis yang diterima adalah hipotesis nol $\left(\mathrm{H}_{0}\right)$ yang menyatakan bahwa ada perbedaan rasio profitabilitas antara PT. Mandom Indonesia Tbk dengan PT. Martina Berto Tbk.

\section{Saran}

Disarankan pada PT. Mandom Indonesia Tbk dan PT. Manrtina Berto Tbk untuk segera melakukan evaluasi perbaikan terutama pada rasio ROE perusahaan, karena berdasarkan hasil penelitian ditemukan permasalahan pada ROE yang terlihat dari nilai ROE yang sangat rendah dan berada dibawah standar yang ada. Hal tersebut menunjukkan bahwa keuangan perusahaan dalam kondisi tidak baik atau sedang mengalami masalah dan bisa saja perusahaan mengalami kerugian bahkan kebangkrutan.

\section{DAFTAR PUSTAKA}

Agnes, Sawir. (2015). Analisa Kinerja Keuangan dan Perencanaan keauangan. Perusahaan. Jakarta : PT. Gramedia Pustaka Utama.

Agus, Harjito dan Martono. (2011). Manajemen Keuangan. Edisi Kedua, Cetakan Pertama,. Yogyakarta : Penerbit EKONISIA.

Harahap, Sofyan Syafri. (2015). Analisis Kritis atas Laporan Keuangan. Edisi 10. Jakarta: Rajawali Pers. 
Hery. (2013). Auditing (Pemeriksaan Akuntansi I). Cetakan Pertama. Jakarta: CAPS.

Kasmir. (2014). Analisis Laporan Keuangan, Edisi Pertama, Cetakan Ketujuh. Jakarta: PT. Rajagrafindo Persada

Marcelina, Silvana. (2013). Analisis Perbandingan Profitabilitas Pada Perusahaan Food And Beverages Yang Terdaftar Di Bursa Efek Indonesia. Jurnal EMBA, 1 (4) : 2264-2274.

Munawir, S. (2010). Analisis laporan Keuangan Edisi keempat. Cetakan Kelima. Belas. Yogyakarta: Liberty.

Nugroho, Muhammad. (2010). Analisis perbandingan kinerja keuangan perusahaan sebelum dan sesudah merger dan akuisisi ( Pada perusahaan pengakuisisi, periode 2002-2003). Skripsi Fakultas ekonomi universitas diponegoro.

Syamsudin, Lukman. (2013). Manajemen Keuangan Perusahaan. Jakarta : PT. Gramedia Pustaka Utama.
Sugiyono. (2013). Metode Penelitian Administrasi. Bandung : Alfabeta.

www.idx.co.id

www.mandom.co.id

www.martinaberto.co.id 